\title{
FARABI
}

Jurnal Pemikiran Konstruktif Bidang Filsafat dan Dakwah

ISSN $1907-0993$

E ISSN $2442-8264$

Vol. 17 No. 1, Juni 2020

\section{KONSEP MAHABBAH RABI'AH AL-ADAWIYAH}

\section{THE CONCEPT OF MAHABBAH RABI'AH AL-ADAWIYAH}

\author{
Kamaruddin Mustamin ${ }^{1}$ \\ ${ }^{1}$ Fakultas Ushuluddin dan Dakwah IAIN Sultan Amai Gorontalo
}

\begin{abstract}
In sufistic discourse, the real journey of life can be said to be a journey to seek God and at the same time a journey to God or at least to God. When the endeavor in that direction is taken seriously, then there are three potential choices that can be made by someone who believes in the existence of God based on the three basic potentials that humans have. If someone is trying to use her services with the potential of using her services, she will strive (mujahid) and try to become a martyr in the way of Allah. If he maximizes the potential of his mind, then he will emigrate with his reasoning power to get closer to the divine truth. If he tries to use his Ruhiyah potential, he will worship to upgrade his piety to the Creator. Rabi'ah al-Adawiyah seems to have sought his sincerity to approach and approach God in a third way. Through the concept of mahabbah that he coined, Rabi'ah al-Adawiyah consistently upgraded his love from ordinary love to extreme love. This effort has tremendous implications for the presence of expressions of love for Allah without any conditions or tendencies. With this extreme expression of love, Rabi'ah believes that she can meet and unite with the Creator. This concept might be judged to leapfrog the epistemology of the Shari'a, but it is personally worthy of being valued as an endeavor that utilizes the spiritual power that potentially belongs to Allah swt., entrust every human being.
\end{abstract}

Keywords: Mahabbah, Rabi'ah Al-Adawiyah, sufistic

\begin{abstract}
Abstrak: Dalam wacana sufistik, perjalanan kehidupan sesungguhnya dapat dikatakan sebagai perjalanan pencarian Tuhan dan sekaligus merupakan perjalanan menuju Tuhan atau minimal mendekati Tuhan. Ketika ikhtiar ke arah itu dilakukan dengan bersungguh-sungguh, maka ada tiga pilihan potensial yang dapat dilakukan seorang yang meyakini adanya Tuhan berdasarkan tiga potensi dasar yang dimiliki manusia. Jika seseorang itu berusaha dengan potensi jasadiah yang dimilikinya maka ia akan berjihad (mujahid) dan berusaha syahid di jalan Allah swt. Jika ia memaksimalkan potensi akalnya maka ia akan berijtihad dengan daya nalarnya untuk menuju lebih dekat kepada kebenaran ilahiah. Jika ia berusaha dengan potensi ruhiyah yang dimilikinya maka ia akan bermujahadah meng-upgrade ketakwaannya kepada Sang Khalik. Rabi'ah al-Adawiyah tampaknya mengupayakan kesungguhannya untuk dekat dan menuju Tuhan dengan cara yang ketiga. Melalui konsep mahabbah yang dicetuskannya, Rabi'ah al-Adawiyah secara konsisten meng-upgrade rasa cintanya dari cinta biasa kepada cinta yang ekstrim. Upaya ini berimplikasi secara luar biasa kepada hadirnya ekspresi cinta kepada Allah swt. tanpa syarat dan tendensi apapun. Dengan ekspresi cinta yang ekstrim inilah Rabi'ah meyakini bahwa ia dapat berjumpa dan bersatu dengan Sang Khalik. Konsep ini bisa jadi dinilai akan melompati epsitemologi syariat tetapi secara personal layak dihargai sebagai suatu ikhtiar yang memanfaatkan daya ruhaniyah yang secara potensial Allah swt. titipkan pada diri setiap manusia.
\end{abstract}

Kata kunci: Mahabbah, Rabiah Al-Adawiyah, susfistik 


\section{FARABI}

Jurnal Pemikiran Konstruktif Bidang Filsafat dan Dakwah

ISSN $1907-0993$

E ISSN $2442-8264$

Vol. 17 No. 1, Juni 2020

\section{A. PENDAHULUAN}

Nama lengkapnya Rabi'ah binti Ismail al-Adawiyah, seorang pemuka sufi abad kedua hijriyah. Ia lahir di Basrah tahun 95 H./713-714 M., pendapat lain mengatakan tahun 99 H./717 M. Dia adalah anak keempat, karenanya diberi nama Rabi'ah yang artinya anak keempat, dari suatu keluarga miskin. Kedua orang tuanya telah meninggal ketika ia masih kecil. Namun hal tersebut tidak membuatnya kehilangan pedoman. Demikian berat cobaan yang dihadapi ia tetap menerimanya dengan sabar dan penuh tawakkal kepada Allah swt.

Pada usia menjelang dewasa, ia pergi dan berpisah dari saudarasaudaranya, namun di tengah perjalanan yang tidak tentu arah, ia ditangkap oleh seorang penjahat lalu menjualnya kepada seseorang dengan harga enam dirham. Sejak saat itu ia menjalani hidupnya sebagai seorang budak ${ }^{1}$. Di siang hari ia harus bekerja berat melayani tuannya dan pada malam hari ia beribadah kepada Allah swt.

Pada suatu malam terjadi suatu peristiwa aneh yang merubah jalan hidupnya; tuannya terjaga dari tidurnya dan melalui jendela melihat Rabi'ah sedang beribadah dan sujud, di atas kepalanya nampak cahaya yang menerangi seluruh rumahnya, dalam ibadahnya Rabi'ah berdoa: "Ya Allah Engkau tahu bahwa hasrat hatiku adalah untuk dapat memenuhi perintah-Mu. Jika Engkau dapat mengubah nasibku ini, niscaya aku tidak akan beristirahat sekejappun dari mengabdi kepada-Mu". Melihat kejadian tersebut, sang tuan merasa takut dan tidak dapat memejamkan matanya hingga menjelang fajar. Pada pagi harinya, ia memanggil Rabi'ah dan memerdeka-kannya. ${ }^{2}$ Sejak saat itu ia menghirup udara kemerdekaannya sebagai manusia.

\footnotetext{
${ }^{1}$ Harun Nasution, Ensiklopedi Islam Di Indonesia, ed. Harun Nasution (Jakarta: Direktorat Jenderal Pembinaan Kelembagaan Agama Islam Departemen Agama RI, 1993).

2 Abdul Mun'im Qandil, Rabi'ah Al-Adawiyah 'Adarau Al-Basrah Al-Batul (Surabaya: Pustaka Progressif, 2000).
} 


\section{FARABI}

Jurnal Pemikiran Konstruktif Bidang Filsafat dan Dakwah

ISSN $1907-0993$

E ISSN $2442-8264$

Vol. 17 No. 1, Juni 2020

Setelah Rabiah bebas, ia memusatkan perhatian pada kegiatan spritual. Di sana ia memiliki suatu majelis yang banyak dikunjungi oleh murid-muridnya yang terdiri dari pada zâhid untuk belajar dan bertukar pikiran. Pada masanya di kota Bashrah sudah mulai ada halaqah (pengajian), yang dirintis oleh Hasan al-Bashri. Namun tak ditemukan data akurat, Rabi ah pernah mengikuti halaqah tersebut dan berguru kepada seorang syaikh atau seorang guru. Namun menurut A. J. Arberry, dia murid tokoh zahid, yaitu Abu Sulaiman ad-Darani ${ }^{3}$. Walaupun demikian Rabi'ah sebenarnya sudah memiliki dasar pengetahuan agama, Sebab sejak kecil Rabi'ah selalu ikut kegiatan ibadah orang tuanya, baik itu ibadah mahdhah atau hanya sekedar membaca al-Qur'an dan berzikir.

Rabi`ah memilih menjalani kehidupannya seorang diri, Rabi`ah tidak pernah kawin, sungguh pun setidaknya ada 2 (dua) orang yang sudah pernah melamarnya untuk berumah tangga ${ }^{4}$. Dalam hidupnya yang yang diarahkan pada dimensi spritual, Rabia'h al-Adawiyah menjauhi kehidupan duniawi (zuhud, ascetic). Ia hidup dalam kemiskinan dan menolak segala bantuan materi yang diberikan kepadanya. Kehidupan Rabia'ah yang ascetic ini bisa dimaklumi, dengan dua pendekatan. Pertama, Rabi'ah menyadari latar belakang hidup keluarganya sebagai orang yang miskin. Secara psikologis pengalaman masa lalunya sebagai orang yang miskin dan bekas budak membawanya untuk tidak perlu hidup bermewah-mewah. Kedua, sebagai seorang sufi, hal pertama yang harus ditempuh sebelum bergumul dalam dimensi spritual ialah kehidupan yang asketik.

Rabi'ah al-Adawiyah menghabiskan sisa hidupnya di Bashrah hingga wafatnya tahun 185 H./801 M. Rabi'ah al-Adawiyah tidak meninggalkan ajaran tertulis. Langsung dari tangannya sendiri. Ajarannya hanya dapat diketahui

\footnotetext{
${ }^{3}$ A.J. Arberry, Pasang-Surut Aliran Tasawuf (Bandung: Mizan, 1985).

${ }^{4}$ Arberry.
} 


\section{FARABI}

Jurnal Pemikiran Konstruktif Bidang Filsafat dan Dakwah

ISSN $1907-0993$

E ISSN $2442-8264$

Vol. 17 No. 1, Juni 2020

melalui para muridnya dan baru dapat dituliskan beberapa tahun setelah kematiannya.

\section{B. KONSEP (MAHABBAH) CINTA RABI'AH AL-ADAWIYAH}

Pengertian yang diberikan kepada mahabbah adalah kecenderungan hati untuk mencintai Allah. Ada juga yang mengartikan mahabbah sebagai ketaatan melaksanakan perintah Allah, menjauhi larangan-larangan-Nya serta ridha terhadap segala ketentuannya ${ }^{5}$.

Harun Nasution menyebut pengertian mahabbah dalam terminologi sufisme sebagai berikut:

1. Mengosongkan hati dari segala-sesuatu kecuali dari Tuhan.

2. Memeluk kepatuhan kepada Tuhan dan membenci sikap melawan kepadaNya.

3. Menyerahkan seluruh diri kepada yang dikasihi ${ }^{6}$

Jadi dapat dipahami bahwa terminologi mistisisme Islam (tasawuf) adalah kecenderungan hati seseorang (sûfi) untuk hanya cinta kepada Allah, mengosongkan bilik-bilik hatinya dari selain Allah, disertai ketaatan melaksanakan perintah-perintah-Nya dan menjauhi larangan-larangan-Nya.

Menurut Imam al-Ghazali, kecintaan kepada Allah dan rasul-Nya adalah fardhu yang ditetapkan berdasarkan dalil-dalil pasti ${ }^{7}$. Munculnya mahabbah ini diinspirasi oleh petunjuk-petunjuk al-Qur'an, antara lain QS al-Ma'idah: 54 dan QS Ali Imran: 30. Kecintaan kepada Allah adalah tujuan yang tertinggi dari maqamat yang dilalui oleh para sufi. Al-Kalabazi membagi mahabbah ini kepada dua macam, yaitu cinta yang hanya dalam pengakuan saja, dan cinta yang dihayati

\footnotetext{
${ }^{5}$ Abu Bakr Muhammad Al-Kalabazi, Al-Ma'rûf Li Mazhab Ahl Al-Tasawwuf (Beirut: Dâr alKutub al-Ilmiyah, 1993).

${ }^{6}$ Harun Nasution, Falsafat Dan Mistitisme Dalam Islam (Jakarta: Bulan Bintang, 1993).

${ }^{7}$ Abu Hamid Muhammad bin Muhammad Al-Ghazali, Ihyâ Ulûm Al-Dîn, Juz IV (Beirut: Dâr alKutub al-Ilmiyah, 1992).
} 


\section{FARABI}

Jurnal Pemikiran Konstruktif Bidang Filsafat dan Dakwah

ISSN $1907-0993$

E ISSN $2442-8264$

Vol. 17 No. 1, Juni 2020

dan diresapi dalam hati keluar dari lubuk hati. Cinta yang pertama ada pada setiap manusia, sedang cinta yang kedua ditujukan hanya kepada Allah. Cinta yang seperti inilah yang dianut dan diamalkan oleh kaum sufi.

Menurut Margaret Smith, Rabi ah dinilai orang pertama yang menyatakan doktrin cinta tanpa pamrih kepada Allah. Di dalam sejarah perkembangan tasawuf, hal ini merupakan konsepsi baru di kalangan para sufi kala itu. Untuk mengetahui lebih jauh tentang konsepsi al-mahabbah atau al-hubb menurut Rabi`ah, akan ditelusuri pernyataannya tentang $\operatorname{cinta}^{8}$.

Pada suatu waktu Rabi `ah ditanya pendapatnya tentang batasan konsepsi cinta. Rabi ah menjawab: Cinta berbicara dengan kerinduan dan perasaan. Mereka yang merasakan cinta saja yang dapat mengenal apa itu cinta. Cinta tidak dapat dijelaskan dengan kata-kata. Tak mungkin orang dapat menjelaskan sesuatu yang belum dikenalnya. Atau mengenali sesuatu yang belum pernah digaulinya. Cinta tak mungkin dikenal lewat hawa nafsu terlebih bila tuntutan cinta itu dikesampingkan. Cinta bisa membuat orang jadi bingung, akan menutup untuk menyatakan sesuatu. Cinta mampu menguasai hati ${ }^{9}$

Pada kesempatan yang lain, ada juga orang yang menanyakan cinta kepada Rabi’ah. Rabi ah juga menjawab, bahwa: Cinta muncul dari keazalian (azl) dan menuju keabadian (abad) serta tidak terlingkupi oleh salah satu dari delapan belas ribu alam yang mampu meminum hatta seteguk serbatnya ${ }^{10}$. Dalam dialog lain, ada 2 (dua) batasan cinta yang sering dinyatakan Rabi ah. Pernyataan pertama, sebagai ekspresi cinta hamba kepada Allah, maka cinta itu harus menutup selain Sang Kekasih atau Yang Dicinta. Dengan kata lain, maka pertama, dia harus memalingkan punggungnya dari dunia dan segala daya tariknya. Lanjutnya kedua,

\footnotetext{
${ }^{8}$ Margareth Smith, Rabi'ah The Mystic and Her Fellow Saints in Islam (Surabaya: Risalah Gusti, 1997).

${ }^{9}$ Qandil, Rabi'ah Al-Adawiyah 'Adarau Al-Basrah Al-Batul.

${ }^{10}$ Smith, Rabi'ah The Mystic and Her Fellow Saints in Islam.
} 


\section{FARABI}

Jurnal Pemikiran Konstruktif Bidang Filsafat dan Dakwah

ISSN $1907-0993$

E ISSN $2442-8264$

Vol. 17 No. 1, Juni 2020

dia harus memisahkan dirinya sesama makhluk ciptaan Allah, supaya dia tak bisa menarik dari Sang Pencipta. Tambahnya ketiga, dia harus bangkit dari semua keinginan nafsu duniawi dan tidak memberikan peluang adanya kesenangan dan kesengsaraan. Karena kesenangan dan kesengasaraan dikhawatirkan mengganggu perenungan pada Yang Maha Suci. Terlihat sekali, Tuhan dipandang oleh Rabi ah dengan penuh kecemburuan sebagai titik konsentrasinya, sebab hanya Dia sendirilah yang wajib dicintai hamba-Nya ${ }^{11}$.

Tentang pernikahan, Rabi'ah memiliki pemikiran sendiri. Baginya akad nikah merupakan hak pemilik alam semesta. Sedangkan baginya, hal tersebut tidak ada karena ia telah berhenti "Maujud" (ada) dan lepas diri. Ia merupakan milik Tuhan, serta ia hidup dalam naungannya. Baginya akad nikah harus dimintakan dari Tuhan, bukan dirinya ${ }^{12}$. Rabi'ah menyadari bahwa menerima pria dalam ikatan pernikahanakan membuat ia tidak adil adil terhadap suami dan anakanaknya kelak ia tak akan mampu memberikan perhatian kepada mereka, karena seluruh hatinya ia serahkan hanya untuk Allah. Rabi'ah tidak menikah bukan semata-mata karena zuhud terhadap pernikahan itu sendiri, melainkan ia zuhud terhadap dirinya ${ }^{13}$

Pernyataan kedua, kadar cinta kepada Allah itu harus tidak ada pamrih apapun. Artinya, seseorang tidak dibenarkan mengharapkan balasan dari Allah, baik ganjaran (pahala) maupun pembebasan hukuman, paling tidak pengurangan. Sebab yang dicari seorang hamba itu melaksanakan keinginan Allah dan menyempurnakannya. Karenanya, kecintaan seseorang itu bisa saja diubah agar lebih tinggi tingkatannya, hingga Allah benar-benar dicintai. Lewat kadar kecintaan inilah, menurut Rabi ah dalam penafsiran Margaret Smith, Allah akan menyatakan diri-Nya sendiri dalam keindahan yang sempurna. Dan melalui jalan

\footnotetext{
${ }^{11}$ Smith.

${ }^{12}$ M. Al-Fatih Suryadilaga, Miftahus Sufi (Yohyakarta: Teras, 2008).

${ }^{13}$ Asep Usmar Ismail, Tasauf (Jakarta: Pusat Studi Wanita, 2005).
} 


\section{FARABI}

Jurnal Pemikiran Konstruktif Bidang Filsafat dan Dakwah

ISSN $1907-0993$

E ISSN $2442-8264$

Vol. 17 No. 1, Juni 2020

cinta inilah, jiwa yang mencintai akhirnya mampu menyatu dengan Yang Dicintai dan di dalam kehendak-Nya itulah akan ditemui kedamaian ${ }^{14}$.

Pada hari yang lain, Rabi`ah menyatakan 2 (dua) macam pembagian cinta, sebagai puncak tasawufnya dan dinilai telah mencapai tingkatan tertinggi dalam tahap cinta. Pembagian cinta tersebut, tertuang dalam lirik syairnya:

"Aku mencintai-Mu dengan dua cinta. Cinta yang timbul dari kerinduan hatiku dan cinta dari anugrah-Mu. Adapun cinta dari kerinduanku Menenggelamkan hati berzikir pada-Mu daripada selain Kamu. Adapun cinta yang dari anugrah-Mu Adalah anugrah-Mu membukakan tabir sehingga aku melihat wajah-Mu Tidak ada puji untuk ini dan untuk itu bagiku Akan tetapi dariMu segala puji baik untuk ini dan untuk itu" ${ }^{, 15}$

Pembagian cinta ini dinilai sebagai pelengkap keteladanan awal suatu peralihan. Sejak saat itu, lambat laun mempengaruhi karakteristik sufisme, yakni pengalihan sufisme dari pola hidup protes terhadap dominasi duniawi (kemewahan hidup ekonomi dan konflik politik), kepada suatu teori kemaujudan dan tatanan teosofi. Karena tasawuf itu pada dasarnya ekstrim ruhaniyah, maka dalam pembagian cinta, Rabi'ah-lah orang yang merintis untuk membelokkan ajaran Islam ke arah mistik yang ekstrim ruhaniyah.

Dialah pelopor yang memperkenalkan cinta ajaran mistik dalam Islam. Dimaksud, terbukanya tabir penyekat alam gaib, sehingga sang sufi akan bisa menyaksikan dan mengalami serta berhubungan langsung dengan dunia gaib dan zat Allah. Kembali ke banyaknya pernyataan cinta Rabi’ah. Muncul pertanyaan, apakah muncul begitu saja, tanpa suatu proses? Dalam penelusuran Muhammad Atiyah Khamis, Rabi`ah telah memperluas beberapa makna ataupun lingkup cinta Ilahi.

\footnotetext{
${ }^{14}$ Ismail.

${ }^{15}$ Simuh, Tasawuf Dan Perkembangannya Dalam Islam (Jakarta: Rajagrafindo Persada, 1996).
} 


\section{FARABI}

Jurnal Pemikiran Konstruktif Bidang Filsafat dan Dakwah

ISSN $1907-0993$

E ISSN $2442-8264$

Vol. 17 No. 1, Juni 2020

Dulu Rabi ah mencintai Allah sebagaimana lazimnya kebanyakan umat Islam, yaitu didorong karena mengharapkan surga Allah dan sebaliknya takut akan neraka-Nya. Ini ternyata jelas melalui pertanyaan doa Rabi ah kepada Allah, yaitu ... "Oh, Tuhan, apakah Engkau akan membakar hamba-Mu di dalam neraka, yang hatinya terpaut pada-Mu, dan lidahnya selalu menyebut-Mu, dan hamba yang senantiasa takwa pada-Mu ${ }^{16}$.

Sesudah Rabi ah menyadari bahwa landasan cinta seperti itu dianggap cinta yang masih sempit, Rabi’ah meningkatkan motivasi dirinya sehingga dia sampai luluh dalam cinta Ilahi. Artinya, dia mencintai Allah karena memang Allah patut untuk dicintai, bukan karena ketakutan terhadap neraka ataupun disebabkan mengharapkan surga-Nya. Ini terlihat, saat Rabi`ah sakit jama`ah menjenguk dan menanyakan keadaannya, dia menjawab, aku tak tahu penyebab penyakitku ini.

Demi Allah, diperlihatkan padaku surga, lalu aku tertarik untuk memilikinya. Mungkin Tuhan cemburu akan sikapku ini, lalu Dia mencelaku. Dia menghendaki agar aku kembali kepada-Nya dan menyadari kesalahanku. Jadi dia tidak ingin menjadi pekerja wanita yang tidak baik. Terus ada peningkatan lagi. Dia justru minta dibakar api neraka, jika menyembah Allah karena takut neraka dan sekaligus mengharamkan surga, kalau dia mengharapkan surga.

Atas dasar cinta dalam penyembahan Allah, dia berkata, limpahkanlah ganjaran yang lebih baik. Dia minta diberi kesempatan melihat wajah Allah Yang Maha Agung dan Maha Mulia, hingga merasa bahagia berada dekat dengan Allah pada hari kebangkitan. Lantas perasaan bahagia itu diakhiri dengan bagiku (Rabi`ah) cukuplah keridlaan-Mu saja.

Wahai, Tuhan! Apabika aku beribadah kepada-Mu hanya karena takut kepada neraka-Mu maka bakarlah aku di neraka-Mu. Dan apabila aku beribadah

\footnotetext{
${ }^{16}$ Muhmmad Atiyah Khamis, Rabi'ah Al-Adawiyah (Jakarta: Pustaka Firdaus, 2000).
} 


\section{FARABI}

Jurnal Pemikiran Konstruktif Bidang Filsafat dan Dakwah

ISSN $1907-0993$

E ISSN $2442-8264$

Vol. 17 No. 1, Juni 2020

kepada-Mu hanya menginginkan surga-Mu maka keluarkanlah aku dari surga-Mu. Tetapi, jika aku beribadah kepada-Mu hanya untuk-Mu semata, berikanlah kepadaku keindahan-Mu yang abadi .

Begitu tingginya kadar kecintaan Rabi`ah kepada Allah hingga pada gilirannya, dia menilai tidur itu tidak saja sebagai bagian dari rangkaian mata rantai ibadahnya, akan tetapi juga sekaligus sebagai musuhnya yang telah menyebabkan berkurangnya ibadah. Perhatikan petikan berikut ini:Wahai Tuhanku, semua manusia telah tidur nyenyak. Raja-raja telah mengunci pintu istana masing-masing. Suami istri telah berbaring di atas sofanya. Namun, Rabi ah yang banyak dosa ini masih bersimpuh di hadapan-Mu. Kebesaran dan Kemuliaan-Mu-lah yang membuat aku terus berjaga malam begini.

Begitu terpusatnya cinta Rabi`ah kepada Allah, pada gilirannya cinta bagi Rabi ah hanya tertuju kepada-Nya. Cinta bagi Rabi ah itu tenggelam dalam renungan mengenai Allah dan berpaling daripada segala makhluk, hingga tidak ada lagi dalam jiwanya perasaan marah atau benci terhadap musuh. Dalam pendalaman studi Margaret Smith, melalui telaah Tadzkirah al-Awliya'-nya Fariduddin al-Aththar, yaitu "Keberadaanku telah tiada dan jati diriku pun telah lenyap. Aku telah menjadi satu dengan-Nya.

Dalam cinta sempurna seperti itu, ahli sufi tak ada lagi dan hilang diri. Aku menyatu dengan-Nya dan sekaligus milik-Nya., harapanku adalah penyatuan dengan-Nya, sebab itulah tujuan dari keinginanku.

\section{KESIMPULAN}

1. Tasawuf dalam Islam memiliki banyak tokoh dengan konsep yang bermacam-macam. Diantaranya adalah konsep cinta (Al-Mahabbah) yang dilahirkan oleh Rabi'atul Adawiyah. Al-Mahabbah adalah konsep dimana adalah seorang hamba tidak lagi memiliki rasa cinta kepada sesama mahluk, tetapi semata-mata hanya diberikan kepada sang pencipta, yaitu Allah SWT. 


\section{FARABI}

Jurnal Pemikiran Konstruktif Bidang Filsafat dan Dakwah

ISSN $1907-0993$

E ISSN $2442-8264$

Vol. 17 No. 1, Juni 2020

2. Konsep Al-Mahabbah tidak lagi memikirkan ketakutan terhadap siksa api neraka, ataupun kepada pengharapan terhadap surga. Tetapi semata-mata karena Tuhan, dan bukan karena mengharap sesuatu. Karena sesungguhnya rasa cinta itu sendiri adalah nikmat yang sangat lezat yang tiada kelezatan diatas cinta tersebut.

\section{DAFTAR PUSTAKA}

Al-Ghazali, Abu Hamid Muhammad bin Muhammad. Ihyâ Ulûm Al-Dîn, Juz IV. Beirut: Dâr al-Kutub al-Ilmiyah, 1992.

Al-Kalabazi, Abu Bakr Muhammad. Al-Ma'rûf Li Mazhab Ahl Al-Tasawwuf. Beirut: Dâr al-Kutub al-Ilmiyah, 1993.

Arberry, A.J. Pasang-Surut Aliran Tasawuf. Bandung: Mizan, 1985.

Ismail, Asep Usmar. Tasauf. Jakarta: Pusat Studi Wanita, 2005.

Khamis, Muhmmad Atiyah. Rabi'ah Al-Adawiyah. Jakarta: Pustaka Firdaus, 2000.

Nasution, Harun. Ensiklopedi Islam Di Indonesia, . Edited by Harun Nasution. Jakarta: Direktorat Jenderal Pembinaan Kelembagaan Agama Islam Departemen Agama RI, 1993.

_. Falsafat Dan Mistitisme Dalam Islam. Jakarta: Bulan Bintang, 1993.

Qandil, Abdul Mun'im. Rabi'ah Al-Adawiyah 'Adarau Al-Basrah Al-Batul. Surabaya: Pustaka Progressif, 2000.

Simuh. Tasawuf Dan Perkembangannya Dalam Islam. Jakarta: Rajagrafindo Persada, 1996.

Smith, Margareth. Rabi'ah The Mystic and Her Fellow Saints in Islam. Surabaya: Risalah Gusti, 1997.

Suryadilaga, M. Al-Fatih. Miftahus Sufi. Yohyakarta: Teras, 2008. 